\title{
"Social Class Categories and Brand-Name Loyalty in Jordan: the Case of the Wearing Apparel"
}

\author{
HuSSEIN ABDUlLA El-OMARI \\ Associate Professor \\ Department of Business Administration \\ College of Business \& Economics \\ United Arab Emirates University \\ United Arab Emirates
}

( Received 1.1.1422H, and Accepted 2.4.1422H )

\begin{abstract}
The influence of social classes on the consumption behavior of their members cannot be underestimated. Based on a quantitative approach, this study examined the link between social class categories and brand-name loyalty, regarding the wearing apparel in Jordan. Using a simple random procedure, a sample of 1000 households of the capital of Jordan (Amman) was selected for this study.

The results suggested that high and upper-middle social class members are loyal to certain brand-names. Lower-middle and low social class members are not loyal to certain brandnames. Jordanian manufacturers of the wearing apparel could make good use of the concepts of social class and brand-name loyalty. This could be reached through promoting an information environment where the psychological influence and the social prestige of the product is promoted.
\end{abstract}

\section{Introduction}

Markets are heterogeneous, they are made of individuals with different product needs and expectations. Even, members of the same family may have different needs and desires. The market variation in needs and desires has led marketers to divide markets into segments, in an attempt to reach individuals who have similar needs and wants. Dividing a whole market into smaller markets consisting of individuals with approximately similar product needs is called market segmentation.

The purpose of segmenting a market is to design a marketing mix that matches the desires of the selected segment. A market segment "is a group of individuals, groups, or organizations who share one or more similar characteristics that cause them to have relatively similar product needs" (Pride and Ferrel, 2000, P. 168). 
There are different ways of segmenting a market. It can be segmented based on demographic factors, geographic factors, psychographic factors and behavioral factors. Social class is related to demographic factors and since the focus of this study is to find out if there is any link between the different social class categories and brand-name loyalty in Jordan, the following literature review will, mainly, cover this issue.

\section{Social Class Categories and Consumer Behavior}

Within every society, individuals rank others into higher, middle and lower social positions of respect. "A social class is an open group of individuals who have similar social rank. A class is referred to as "open" because people can move into and out of it. The criteria used to group people into classes vary from one society to another," (Pride and Ferrel, 2000, P. 210).

Most writers and researchers (e.g., Richard Coleman 1983, p. 267; Tim Triplett, 1994 pp. 1-11; James E., Roger D., 1995, p. 4) have reported that, consumers with similar social classes develop similar patterns of behavior. Social class influences many aspects of our lives. For example, it affects our chances of having children and their chances of surviving infancy. It influences our occupation, religion, childhood training, and educational attainment. Because social class affects so many aspects of a person's life, it also influences buying decisions.

In the complicated world of business, marketers have relied on various ways of the concept of social class in studying consumers' behavior and market segmentation. The social class approach, in studying consumers, has added valuable details to other consumer behavior concepts. For example, in their study on "Intermarket patronage: A psychographic study of consumer outshoppers", concluded a high social class profile of buying behavior. Reynolds and Darden (1972, pp. 50-54) wrote:

\footnotetext{
"When compared to the infrequent out-shopper, tend to be better educated, has a higher income level, ..., prefers to shop in the evening, is a more frequent buyer by maiL.... Frequent out-shoppers, as defined here, tend to be very active and urban-oriented, yet neither time-conscious nor loyal to any particular store. Furthermore, they express an over all dissatisfaction with local shopping conditions and a strong preference for larger urban shopping areas. Out-shopping behavior was found not to be product specific, but applicable to many types of merchandise".
}

Other studies, (e.g., Pierre and Ritchie 1980, p. 139; Gary Jerry 1982, p. 14; Richard Coleman 1983, p. 267; Henry Assael 1987, p. 364; Stowe Shoemaker, 1994, p. 20; Basil and Michael, 1995, p. 13; Ian MacMillan and Rita MacGrath, 1997, p. 134) reported similar results and provided the descriptions of consumer activities and their linkage to individual's social class.

\section{Social class and brand loyalty}

Previous research, (e.g., Bruce and Dommermuth 1968, p. 6; Fry and Stiller 1970, p. 335; Richard Coleman 1983, p. 267; Anderson and Ratchford 1987, p. 190; Henry Assael 1987, p. 364) reported a positive link between consumer's social class and brand loyalty. For example, Richard Coleman reported a positive relationship between upper social classes and the number of stores visited in search of a brand. He, also, found more frequent shopping behavior in the upper social classes. 
The emphasis of previous research was on explaining why consumers choose a particular product and on describing the social class characteristics of the buyer. Some researchers have concluded that high social class consumers lead an active, urban existence and out-of-home activities as leadership of clubs or societies. These activities may require the concerned consumer to be associated with certain brands of products. Social scientists have endorsed social class membership as a determinant of consumption behavior. The phenomena on that consumers' behavior is largely affected by a frame of influences produced by members of the social class to which they belong is long-accepted (Aaker D. and Keller K., 1990, p. 30; Sherry J. 1990, p. 15; Aaker D. 1991, p. 60; Mehta R. and Russel B. 1991, p. 402; Macklin C. 1996, p. 257).

In addition to examining the existence of social class influences within identifiable groups, there have been a number of consumer studies into specific aspects of social class influence on brand loyalty. Richard Coleman (1983, p. 267) reported that consumers use evaluations of their social class members to choose a brand. This is true, especially, when consumers hold favourable attitudes toward members or activities of that social class. The concept of social class and brand choice was also studied by others (e.g., Bruce and Dommermuth 1968, p. 5; Olsen B. 1996, p. 270; Douglas H. 1997, p. 341; Alex C. 1997, p. 307) and reported that cohesiveness of social class members influences brand choice of each other.

This concept has been used by advertisers in their efforts to persuade consumers to purchase products and brands. The portraying of products as being consumed in socially pleasant situations, the use of prominent/attractive people endorsing products, and the use of obvious social class members as spokespersons in advertisements, are all evidence that marketers and advertisers make substantial use of potential social class influence on consumer behavior in the advertising campaign of their promotional mix strategy (Leon Schiffman and Leslie Kanuk, 1997, p. 32). The symbolic importance of the product and the structure of social class members affect the level of influence on consumers' brand choice.

It can be concluded that social class members can have a major influence on the purchase of conspicuous goods and services. A brand is conspicuous to the extent that it can be seen and identified by others.

Although education, job and income are considered as the main factors in determining a person's social class, other researchers (e.g., Joseph Plummer 1974, p. 34; Leon Schiffman and Leslie Kanuk 1997, p. 48; Pride and Ferrel 2000, pp. 210) have stressed the importance of including other social activities of the person. Therefore, the following variables are used in this study to determine a person's social class category in Jordan:

a- Education

b- Job

c- Income

d- Hobbies

e- Social events

f- Vacation

g-Entertainment 
h-Club membership

i- Community

j- Shopping

k- Sports

\section{Objective of the study}

The main objective of this research was to evaluate the influence of consumer's social class category on brand-name loyalty, regarding the wearing apparel. This objective was reached through:

a) Developing a method of identifying respondents' social class categories.

b) Examining the influence of consumers' social class categories on brand name loyalty.

\section{Study Hypotheses}

Based on the literature review and the researcher's familiarity with the Jordanian society, the following hypotheses were formulated:

H1 "No significant difference exists between the means of Jordanians' high and uppermiddle social class categories, regarding brand-name loyalty of the wearing apparel"

H2 "A significant difference exists between the means of Jordanians' high and lowermiddle social class categories, regarding brand-name loyalty of the wearing apparel"

H3 "A significant difference exists between the means of Jordanians' high and low social class categories, regarding brand-name loyalty of the wearing apparel"

H4 "A significant difference exists between the means of Jordanians' low and uppermiddle social class categories, regarding brand-name loyalty of the wearing apparel"

H5 "No significant difference exists between the means of Jordanians' low and lowermiddle social class categories, regarding brand-name loyalty of the wearing apparel"

\section{Research Methodology}

Questionnaire Development and Data Collection:

Questionnaire Development

Developing study constructs was one of the main concerns of this research. In doing so, the researcher borrowed heavily from the literature (e.g., Bruce and Dommermuth 1968, pp. 1-7; Fry J. and Siller F. 1970, pp. 333-337; Joseph Plummer 1974, p. 34; Richard Colman 1983, p. 267; Stowe Shoemaker, 1994, pp. 8-21; George Moschis, 1996, pp. 44-50; Ian MacMillan and Rita McGrath, 1997, pp. 133-145; Pride and Ferrel 2000, pp. 193-213). This was done to ensure content validity and reliability of all constructs. In addition, reliability analysis was also conducted and the results were encouraging (Alpha values >.65 suggested by Nunnally J., 1978, pp. 52-67).

The English version of the questionnaire was translated into Arabic and, this version was subject to a pilot test study on a small convenience sample of 100 households. This was done to avoid ambiguity, complexity and to be as accurate as possible. 


\section{Data Collection}

Data was collected from Amman and the surrounding suburbs and with regard to the wearing apparel. The wearing apparel was selected as it is always considered by Jordanian consumers as specialty products and, therefore, social classes could have an influence on brand-names. The questionnaire carried a statement which says "wherever appropriate, please, answer the following questions with regard to the wearing apparel". Amman was chosen as an area of study as it has a cross-section of Jordanians, representing all social categories. According to Jordans' Statistical Yearbook No. 47 of September 1997 (the latest), Amman had a population of 1.696.300 and, therefore, a sample of 1000 households was selected from the files of the Water Authority, using a simple random procedure. Taking into account the size of the population of Amman and the nature and the type of this study, this sample size was thought to be adequate see, for example, Tull and Hawkins, 1987, p. 397). After that, 1000 questionnaires, with mainly 5-point Likert-type scales, were hand delivered. In doing so, the researcher received the help of seven assistants, all of them are management graduates (B.Sc. holders). Moreover, the researcher also explained the objective and importance of this study to his assistants.

Of the 1000 distributed questionnaires, 960 were returned. 116 of the returned questionnaires were either hardly answered or not answered at all. This left the researcher with 844 usable questionnaires, which were used in the statistical analysis. The method used in delivering and collecting the questionnaire gave a response rate of $84.4 \%$.

\section{Analysis and discussion:}

As mentioned under the section "objective of the study", the main concern of the researcher was to find a method that can be used in identifying Jordanians' social class categories and then, to examine the influence of these categories on consumers' brandname loyalty.

\section{Identifying respondents according to their social class categories:}

Table (1) shows the frequencies and the mean values of respondents' answers to the statements Qla, Qlb, ..., Qlk. These statements adopted from a study conducted by Joseph Plummer (1974, p.34) and are going to be used to identify respondents' social class categories.

For the purpose of identifying respondents' social class categories, it could be argued that, respondents who score very highly on the eleven characteristics (i.e., Qla, $\mathrm{Qlb}, \ldots, \mathrm{Q} 1 \mathrm{~K})$ are more likely to be of high social class than low social class and viceversa. The rest of the sample could be classified as upper-middle and lower-middle social classes.

To isolate from the sample those who scored very highly on the eleven variables and those who scored very low, the aggregate score was taken by a simple mathematical procedure (i.e., Qla + Qlb $+\ldots+\mathrm{Q} 1 \mathrm{~K}$ ). If the distribution of the sample on the aggregate score is normal, then high social class respondents could be classified as those scoring $>$ the mean value + standard deviation, and low social class respondents as those scoring < the mean value - standard deviation. For those who 
scored $>\mathrm{M}$ but $<\mathrm{M}+$ could be classified as upper-middle social class. For those who scored $<\mathrm{M}$ but $>\mathrm{M}$ - could be classified as lower-middle social class.

Table (1)

Frequencies of Respondents' answers to the statements given in question No. 1.

\begin{tabular}{|c|c|c|c|c|c|c|c|c|c|c|c|}
\hline \multicolumn{3}{|c|}{ Level of agreement } & \multicolumn{2}{|c|}{$\begin{array}{l}\text { St. } \\
\text { agree }\end{array}$} & \multicolumn{2}{|c|}{ Agree } & \multicolumn{2}{|c|}{ Uncertain } & \multicolumn{2}{|c|}{$\begin{array}{l}\text { disagree } \\
\text { disagree }\end{array}$} & \multirow{2}{*}{$\begin{array}{l}\begin{array}{l}\text { St. Mean } \\
\text { value }\end{array} \\
\%\end{array}$} \\
\hline Statemen & & $\mathrm{n}$ & $\%$ & $\mathrm{n}$ & $\%$ & $\mathrm{n}$ & $\%$ & $\mathrm{n}$ & $\%$ & $\mathrm{n}$ & \\
\hline \multirow[t]{2}{*}{ Q1a } & \multicolumn{11}{|c|}{$\begin{array}{l}\text { my level of education is considered of high levels in Jordan and schooling is very important } \\
\text { to me and to my family. }\end{array}$} \\
\hline & 198 & 23.4 & 202 & 23.9 & 204 & 24.2 & 150 & 17.8 & 90 & 10.7 & 3.32 \\
\hline \multirow[t]{2}{*}{ Q1b- } & My jc & s cons & ered in & rdan as & prest & ous. & & & & & \\
\hline & 148 & 17.6 & 180 & 21.3 & 250 & 29.6 & 140 & 16.6 & 126 & 14.9 & 3.10 \\
\hline \multirow[t]{2}{*}{ Qlc- } & My le & 1 of inc & me is c & sidered & f high & rels in $J$ & rdan. & & & & \\
\hline & 138 & 16.4 & 152 & 18.0 & 202 & 23.9 & 112 & 13.3 & 240 & 28.4 & 2.81 \\
\hline \multirow[t]{2}{*}{ Q1d- } & I have & hobby & g., pla & ng pian & painti & etc.) $\mathrm{tl}$ & t I aly & s fulfil. & & & \\
\hline & 192 & 22.7 & 176 & 20.9 & 220 & 26.1 & 134 & 15.9 & 122 & 14.4 & 3.22 \\
\hline \multirow[t]{2}{*}{ Q1e- } & I alw & celebr & e socia & vents of & my fa & ly (e.g. & weddi & days, b & hdays, & & \\
\hline & 174 & 20.6 & 236 & 28.0 & 206 & 24.4 & 102 & 12.1 & 126 & 14.9 & 3.27 \\
\hline \multirow[t]{2}{*}{ Qlf- } & $\begin{array}{l}\text { I am } \\
\text { or tra }\end{array}$ & $\begin{array}{l}\text { ays in } \\
\text { aboar }\end{array}$ & ested i & ny vaca & Ion anc & herefor & I spen & somev & ere aw & from $t$ & house \\
\hline & 106 & 12.6 & 124 & 14.7 & 138 & 16.3 & 178 & 21.1 & 298 & 35.3 & 2.48 \\
\hline \multirow[t]{2}{*}{ Q1g- } & I am & rays in & ested i & ny ente & ainmes & thus I g & to par & muse & ns, din & s, etc. & \\
\hline & 94 & 11.1 & 158 & 18.7 & 236 & 28.0 & 152 & 18.0 & 204 & 24.2 & 2.75 \\
\hline \multirow[t]{2}{*}{ Q1h- } & $\begin{array}{l}\text { I have } \\
\text { of any }\end{array}$ & $\begin{array}{l}\text { club } n \\
\text { cial cl }\end{array}$ & $\begin{array}{l}\text { nbersh } \\
\text { in Jor }\end{array}$ & $\begin{array}{l}\text { (e.g., } \mathrm{m} \\
\mathrm{n} \text { or els }\end{array}$ & $\begin{array}{l}\text { mbersl } \\
\text { where) }\end{array}$ & of the & achers & $\mathrm{db}$ in $\mathrm{J}_{\mathrm{c}}$ & lan, or & y mem & rship \\
\hline & 194 & 23.0 & 206 & 24.4 & 212 & 25.1 & 140 & 16.6 & 92 & 10.9 & 3.32 \\
\hline \multirow[t]{2}{*}{ Q1i- } & $\begin{array}{l}\text { The t } \\
\text { live is }\end{array}$ & $\begin{array}{l}\text { of co } \\
\text { ery im }\end{array}$ & $\begin{array}{l}\text { munity } \\
\text { rtant to }\end{array}$ & $\begin{array}{l}\text { g., thei } \\
\text { e. }\end{array}$ & level & educat & $n$, job & 1 incom & wher & would & e to \\
\hline & 310 & 36.7 & 224 & 26.5 & 172 & 20.4 & 76 & 9.0 & 62 & 7.4 & 3.76 \\
\hline \multirow[t]{2}{*}{ Q1j- } & $\begin{array}{l}\text { The } n \\
\text { impol }\end{array}$ & ne of th & place $n$ & $\begin{array}{l}\text { re I wo } \\
\text { e impor }\end{array}$ & $\begin{array}{l}\text { ld like } \\
\text { ant tha }\end{array}$ & $\begin{array}{l}\text { shop a } \\
\text { he price }\end{array}$ & the $b$ & d name & the $p$ & uct are & \\
\hline & 86 & 10.2 & 138 & 16.4 & 238 & 28.2 & 126 & 14.9 & 256 & 30.3 & 2.61 \\
\hline \multirow[t]{2}{*}{ Q1K- } & I alw & practi & sport & ., tenni & & & & & & & \\
\hline & 232 & 27.5 & 240 & 28.4 & 152 & 18.0 & 80 & 9.5 & 140 & 16.6 & 3.41 \\
\hline
\end{tabular}

The distribution of the sample on the aggregate score was approximately normal, as the sample skewness and the kurtosis were small (-.04 and -.64 consequently). Therefore, high, upper-middle, lower-middle and low social class respondents were classified on the basis of the following conditions:

a. When the score for some respondents on the aggregate of $(\mathrm{Q} 1 \mathrm{a}+\mathrm{Q} 1 \mathrm{~b}+\ldots+\mathrm{Q} 1 \mathrm{~K})$ $>\mathrm{M}+\sigma$, then those respondents could be classified as high social class.

b. When the score for some respondents $>\mathrm{M}$ but $<\mathrm{M}+\sigma$ on the aggregate of Q1a + $\mathrm{Q} 1 \mathrm{~b}+\ldots+\mathrm{Q} 1 \mathrm{k})$, then those respondents could be classified as upper-middle social class. 
c. When the score for some respondents on the aggregate of $(\mathrm{Q} 1 \mathrm{a}+\mathrm{Q} 1 \mathrm{~b}+\ldots+\mathrm{Q} 1 \mathrm{k})<$ $\mathrm{M}-\sigma$, then those respondents could be classified as low social class.

d. When the score for other respondents $<\mathrm{M}$ but $>\mathrm{M}-\sigma$ on the aggregate of $(\mathrm{Qla}+$ $\mathrm{Qlb}+\ldots+\mathrm{Qlk})$, then those respondents could be considered as lower-middle social class.

Based on the analysis, Table (2) shows the number of respondents who were classified as high social class, upper-middle social class, lower-middle social class, and low social class.

Table (2)

Number of respondents and the different social class categories

\begin{tabular}{lcc}
\hline \multicolumn{1}{c}{ Category } & n & \% \\
\hline - Respondents who were classified as high social class. & 168 & 19.9 \\
- Respondents who were classified as upper-middle social class. & 250 & 29.6 \\
- Respondents who were classified as lower-middle social class. & 254 & 30.1 \\
- Respondents who were classified as low social class. & 172 & 20.4 \\
& & \\
\hline
\end{tabular}

$\mathrm{n}=$ number of cases included in the sample

0 missing value

The following figure shows the distribution of the sample on the aggregate score of $(\mathrm{Q} 1 \mathrm{a}+\mathrm{Q} 1 \mathrm{~b}+\ldots+\mathrm{Q} 1 \mathrm{k})$ and, also, shows the four social class categories.

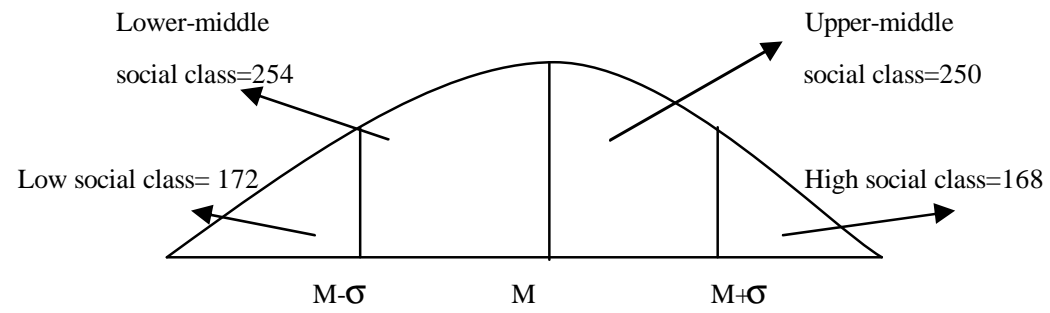

Figure (1)

As can be seen from Table (2) and Figure 1, 168 respondent (i.e., 19.9\%) have scored $>\mathrm{M}+\sigma$ on the aggregate score of the eleven variables. Those respondents could be considered of high social class category. On the other hand, 172 respondent (i.e., 20.4\%) have scored $<M-\sigma$ on the aggregate score, hence, those respondents could be classified into low social class category. The rest of the sample (i.e., 504 respondent) could be classified as, 250 respondent of upper-middle social class category and 254 respondent of lower-middle social class category. 


\section{Respondents' frequencies regarding brand-name loyalty:}

To examine respondents' brand-name loyalty, three statements, i.e., Q2a, Q2b and Q2c were used. The three statements were used to double check on respondents' answers and get more reliable information. Table (3) shows the results.

Table (3)

Frequencies of respondents' answers regarding brand-name loyalty

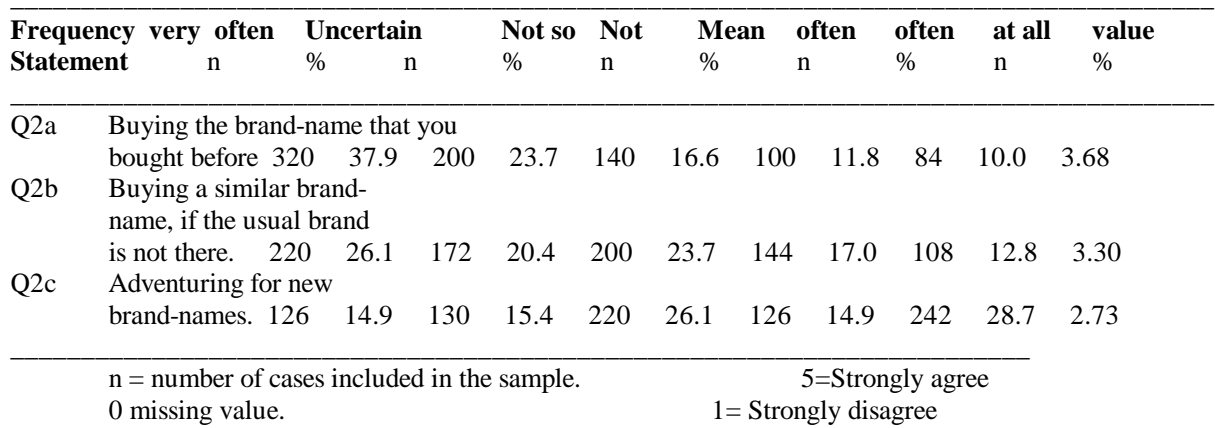

Table (3) shows that the majority of respondents would strongly rebuy the brandname they bought before or buy a similar brand-name with mean values of 3.68 and 3.30 consecutively. However, this was not the case when adventuring for new brandnames with a mean value of 2.73. This purchase strategy of Jordanians could be explained through the following:

a. Jordanians who belong to high and upper-middle social class categories would stick to certain brand-names to be perceived as prestigious and to be seen as different from other Jordanians who belong to other social class categories.

b. Jordanians who belong to lower-middle and low social class categories earn less income than other Jordanians who belong to high and upper-middle social class categories and, therefore, they stick to certain brand-names as a risk ${ }^{(*)}$ reduction method.

\section{Respondents' social class categories and brand-name loyalty}

To examine if there was any significant difference between Jordanians who belong to high, upper-middle, lower-middle, and low social classes and brand-name loyalty, the following statistical procedures were conducted. These procedures were also used to test the study hypothesis.

As mentioned earlier, three statements ${ }^{(* *)}$ (i.e., Q2a, Q2b and Q2c) were used to investigate respondents' brand-name loyalty. For the purpose of combining these three statements, reliability analysis was carried out and the results gave encouraging results (Cronbach Alpha $=.78>.65$ suggested by Nunnally, 1978 and others). As a result, the

\footnotetext{
* Risk could be financial, operational, social and psychological.

** Content validity was achieved through the use of measurements mainly used in previous studies.
} 
three statements (i.e., Q2a, Q2b and Q2c) were used combined together and $\mathrm{a}^{(+)} \mathrm{T}$ - test was conducted to find out the following (with respect to brand-name loyalty)

a. If there is a significant difference between the means of high and upper-middle social class respondents.

b. If there is a significant difference between the means of high and lower-middle social class respondents.

c. If there is a significant difference between the means of high and low social class respondents.

d. If there is a significant difference between the means of low and upper-middle social class respondents.

e. If there is a significant difference between the means of low and lower-middle social class respondents.

Table (4) reveals a summary of the T-test results.

Table (4)

Respondents' different social class categories by brand-name loyalty

\begin{tabular}{lcccccc}
\hline \multicolumn{1}{c}{ Social class category } & level & $\mathrm{n}$ & $\mathrm{N}$ & T-value & $\mathrm{df}$ & level of significance \\
\hline a. High versus upper- middle & L & 168 & 418 & 1.25 & 416 & - \\
b. High versus lower-middle & H & 168 & 672 & 3.98 & 670 & $* *$ \\
c. High versus low & H & 168 & 422 & 5.85 & 420 & $* *$ \\
d. Low versus upper- middle & H & 250 & 422 & 3.87 & 420 & $* *$ \\
e. Low versus Lower - middle & L & 254 & 426 & 1.27 & 424 & -
\end{tabular}

1- The results for each category (i.e., a, b, c, d and e) were performed separately. For example, a T-test analysis was carried out between high and upper-middle social class categories, regarding brand-name loyalty. Category (a) shows the results.

$\mathrm{n}=$ number of valid observations.

$\mathrm{N}=$ Number of cases included in the test.

** Significant difference at the 0.01 level.

- No significant difference was found.

The statistical results shown in Table 4 can be summarized as follow:

a. There is no significant difference between the means of high social class and uppermiddle social class respondents, regarding brand-name loyalty. This suggests that respondents of upper-middle social class category have a high level of brand-name loyalty, which explains the insignificant difference between this social class category and high social class category.

b. Respondents of high social class have a higher level of significant difference than respondents of lower-middle social class, regarding brand-name loyalty at the 0.01 level. This significant difference could be related to the fact that, high social class individuals, in Jordan and elsewhere, earn a significantly higher level of income than individuals of other social classes, hence, individuals of this social category tend to buy well-known brand-names.

+ Conditions of using a T-test were met. 
c. Respondents of high social class category have a significantly higher level of brandname loyalty than respondents of low social class category at the 0.01 level.

d. The results show that respondents of upper-middle social class category have a significantly higher level of brand-name loyalty than respondents of low social class category at the 0.01 level.

e. No significant difference was found between the means of low and lower- middle social class categories, regarding brand-name loyalty.

The reasons that could be used to explain the significant differences between the different social class categories, are:

1. Respondents of high social class category in Jordan have better financial capabilities than respondents of other social class categories. This privilege may have made them loyal to brand-names that they feel more comfortable with, even if psychologically, than other brand-names.

2. The insignificant difference between high and upper-middle social classes could be explained through the tendency amongst large segment of Jordanians to show themselves as high social class members. Hence, imitation of high social class individuals may have made upper-middle social class members become loyal to certain brand name(s).

The study hypotheses (i.e., H2, H3 and H4 ) were accepted at the level of 0.01 . On the other hand, the other hypotheses ( i.e., H1, and H5 ) were rejected.

Based on the above analyses, it can be added that low social class members in Jordan are, generally, poor which means that their main concern is the price of the product and not the brand-name. Moreover, the influence of social class members on each other should not be underestimated. This influence may determine the quality and the brand-name of the product to be bought. This is true as the social norms and ties in Jordan make all members of any social class very close.

3. Low and lower-middle social classes have less financial capabilities than high and upper-middle social classes. To reduce the level of financial risks associated with buying a brand-name(s), they (low and lower-middle social classes) may search for the wearing apparel that could serve their needs without sticking to a particular brand-name(s), and without causing any financial burden on their budgets.

\section{Conclusions and Recommendations}

The influence of social class members on each other has long been realized by marketers and researchers. Customers often buy products similar to what their social class and business associates own, hence, it is important to study the type of the membership in any social class. For consumer goods, buyers are sometimes grouped into social classes based on occupation, source of income, type of housing, residence location and other activities. It is important to remember that, social class membership often determines when people buy and what they buy.

The findings of this study suggest that, high and upper-middle social class members are loyal to certain brand-names that could serve and maintain the 
psychological and social prestige that they hold of themselves. On the contrary, lowermiddle and low social classes in Jordan make less money and, therefore, the price of the product is more important to them than the brand-name. These social classes are usually poor and satisfying their needs is the main issue regardless of the brand-name.

The strong social norms and ties in Jordan make social classes have strong influence on their members. It can safely be said that social classes may determine the type and quality of products that a member person can buy and use. Shopping patterns and the type of stores visited can also be affected by social classes. If someone examines advertising messages worldwide, the general conclusion will be that many of these messages are based on an appeal to a specific social class.

The concepts of social classes and brand-name loyalty have proved useful in many areas of promotion and marketing, therefore, they deserve an important place in studies of consumer behavior especially in developing countries, such as Jordan, as this subject is widely neglected. Jordanian manufacturers of the wearing apparel and their marketers need to have clear understanding of these two concepts and other concepts of consumer behavior. Marketers of those manufacturers need to understand the structure of social classes and their consumption styles before they can think of satisfying consumers' needs and wants. This will make their job a lot easier and their level of competition will be enhanced.

In there marketing activities, Jordanian manufacturers of the wearing apparel could make good use of the concepts of social class and brand-name loyalty. This could be done by stimulating a product's awareness and interest by creating an information environment where the psychological influence and the social prestige of the product is promoted. For example, employing well known persons to create favourable personal communication to promote a product's social prestige and to act as intermediaries in their areas could help in ensuring awareness and creating the desirability of the purchase. This is vital since the psychological influence and the social prestige exert an important impact on Jordanians' ( high and upper-middle social classes ) purchase decisions of the wearing apparel, as well as creating a state of confidence in their minds. Employing well-known persons to promote the psychological influence and the social prestige is not limited to personal communication. Those manufacturers should use other sources of information (e.g., TV advertising, showrooms, magazines, leaflets,..., etc.). This procedure should help in spreading the social prestige of the wearing apparel which, in turn, would improve the sales volume and obtain more rapid positive information diffusion about a particular product.

This study did not answer questions as to how these social class categories could be used in developing proper marketing strategies? What should be done to make the current ones more effective? And how the different income levels could affect the different social class categories regarding brand-name loyalty? In addition, this study did not investigate social class categories and brand-name loyalty with regard to sex. These issues are left for future research. 


\section{References}

Aaker, D. (1991). Managing Brand Equity. New York: The Free Press, USA.

Aaker, D. and Keller, K. (1990). Consumer Evaluations of Brand Extensions, Journal of Marketing, 54(1), pp27-41.

Alex Chernev. (1997). The Effect of Common Features on Brand Choice: Moderating Role of Attribute Importance, Journal of Consumer Research, 4(March), pp. 304-311.

Anderson, A., and Ratchford, B. (1987). Factors Affecting Consumer Use of Information Sources, Journal of Business Research, 5(August), pp. 179-212.

Basil G. Englis and Michael Solomon. (1995). To Be or Not to Be: Life Style Imagery, Reference Groups, and the Clustering of America, Journal of Advertising, March, p.13.

Bruce, G. and Dommermuth, W. (1968). Social Class and Differences in Shopping Activities, Marquette Business Review, 12 (Spring), pp. 1-7.

Douglas, Holt. (1997). Poststructuralist lifestyle Analysis: Conceptualizing the Social Patterning of Consumption in Post Modernity, Journal of Consumer Research, 4(March), pp. 326-350.

Fry, J. and Siller, F. (1970). A Comparison of Housewife Decision Making in Two Social Classes, Journal of Marketing Research, 7(August), pp. 333-337.

Gary, Jery. (1982). Y and R Study: New Life to Singles, Advertising Age, 4(October), P. 14.

George P. Moschis. (1996). Life Stages of the Mature Market, American Demographics, September, pp.44-50.

Henry Assael. (1987). H., Consumer Behavior and Marketing Action, Boston. Kent Publishing Company, p. 364.

Ian C. MacMillan and Rita Gunther McGrath. (1997). Discovering New Points for Differentiation, Harvard Business Review, July-August, pp.133-145.

James E., Roger D, and Paul M. (1995). Consumer Behavior, 8th ed., Hinsdale, ILL. : Dryden Press, p.4, USA.

Joseph Plummer. (1974). The Concept and Application of Life Style Segmentation, Journal of Marketing, 2 (January), p.34.

Leon G. Schiffman and Leslie Kanuk. 1997. Consumer Behavior, 6 ed., Upper Saddle River, NJ: Prentice Hall, USA.

Macklin Carole. (1996). Preschooler's Learning of Brand Names from Visual Cues, Journal of Consumer Research, 3 (December), pp. 251-26 1.

Mehta, Raj and Russel. Belk. (1991). Artefacts, Identity and Transition: Favourite Possessions of Indian and Indian Immigrants to the United States", Journal of Consumer Research, 17 (March), pp. 398-411.

Michael R. Solomon. (1998). Consumer Behavior, 4th ed., (Upper Saddle River, NJ: Prentice Hall, USA.

Nunnally, J. (1978). Psychometric Theory, 2nd edition, McGraw-Hill Book Company, New York, USA.

Olsen, Barbara. (1996). Brand Loyalty and Consumption Patterns: The Lineage Factor, Journal of Consumer Research, 3 (December), pp.245-281.

Pierre, Filiatralt and Ritchie, Brent. (1980). Joint Purchase Decision: A Comparison of Influence Structure in Family and Couple Decision-Making Units, Journal of Consumer Research, 7 (September), p. 139.

Pride, W. and Ferrell, 0. C. (2000). Marketing, 2000 edition, Boston: Houghton Mifflin Company, USA.

Reynolds and Darden. (1972). Intermarket Patronage: A Psychographic Study of Consumer Out-Shoppers, Journal of Consumer Research, 8 (October), pp, 5-54.

Richard Coleman. (1983). The Continuing Significance of Social Class in Marketing, Journal of Consumer Research, 10 (December), P. 267. 
Sherry John. (1990). A Sociocultural Analysis of a Midwestern American Flea Market, Journal of Consumer Research, 17 (June), pp. 13-30.

Stowe Shoemaker. (1994). Segmenting the U.S. Travel Market According to Benefits Realized, Journal of Travel Research, Winter, pp. 8-21.

Tim Triplett. (1994). Consumers Show Little Taste for Clear Beverages, Marketing News, May $23, \mathrm{pp} .1,11$.

Tull D. and Hawkins D. (1987). Marketing Research : Measurement and Method. 4th edition, Macmillan Publishing Company, New York, USA, P.397. 


\section{Appendix}

\section{Questionnaire}

Wherever appropriate, please, answer the following questions with regard to the wearing apparel.

Q 1 - To what extent would you agree or disagree with the following statements?

Strongly Agree Uncertain disagree strongly agree

disagree

a) My level of education is considered of high levels in Jordan and schooling is very important to me and to my family.

b) My Job is considered in Jordan as prestigious.

c) My level of income is considered of high levels in Jordan.

d) I have a hobby (e.g., playing piano, painting, etc.) that I always fulfil.

c) I always celebrate the social events of my family (e.g., wedding days, birthdays, etc.)

f) I am always interested in my vacation and, therefore, I spend it somewhere away from the house or travel abroad

g) I am always interested my entertainment, thus, I go to parties, museums, dinners, etc.

h) I have a club membership (e.g., membership of the teachers' club in Jordan or any membership of any social club in Jordan or elsewhere

i) The type of community (e.g., their level of education, job and income) where I would like to live is very important to me.

j) The name of the place where I would like to shop and the brand-name of the product are very important to me, even more important than the price.

k) I always practice sports (e.g., tennis).

$\begin{array}{lllll}5 & 4 & 3 & 2 & 1 \\ 5 & 4 & 3 & 2 & 1 \\ 5 & 4 & 3 & 2 & 1 \\ 5 & 4 & 3 & 2 & 1 \\ 5 & 4 & 3 & 2 & 1 \\ 5 & 4 & 3 & 2 & 1 \\ 5 & 4 & 3 & 2 & 1 \\ & & & & \\ 5 & 4 & 3 & 2 & 1 \\ & & & & \\ 5 & 4 & 3 & 2 & 1 \\ 5 & & & & \\ 5 & 4 & 3 & 2 & 1 \\ 5 & & 3 & 2 & \end{array}$

\section{Q2 - How often do you do the following?}

a) Buying the brand-name that you bought before.

b) Buying a similar brand-name, if the usual brand is not here.

c) Adventuring for new brand-names.

\begin{tabular}{|c|c|c|c|c|}
\hline $\begin{array}{l}\text { Very } \\
\text { Often }\end{array}$ & Often & $\begin{array}{l}\text { Uncertain } \\
\text { often }\end{array}$ & $\begin{array}{c}\text { Not so } \\
\text { all }\end{array}$ & Not a \\
\hline 5 & 4 & 3 & 2 & \\
\hline 5 & 4 & 3 & 2 & \\
\hline 5 & 4 & 3 & 2 & \\
\hline
\end{tabular}




$$
\begin{gathered}
\text { الطبقات الاجتماعية والو لاء السلعي في الأردن : الملابس الجاهزة كحالة دراسية } \\
\text { الماهية }
\end{gathered}
$$

\section{حسين عبدالله العمري}

$$
\text { أستاذ مشارك }
$$

قسم إدارة الأعمال - كلية الاقتصاد والتجارة

جامعة الإمارات المتحلدة - الإمارات الإعمات العربية المتحلدة

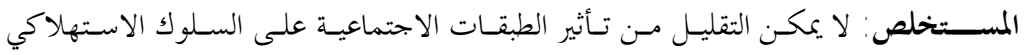

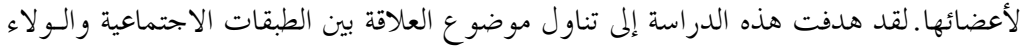

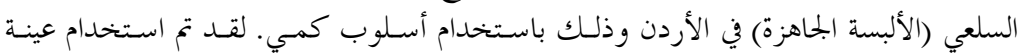

$$
\begin{aligned}
& \text { عشو ائية بسيطة مكونة من ل . . الأبسة أسرة ممن يقطنون في العاصمة الأردنية - عمان. }
\end{aligned}
$$

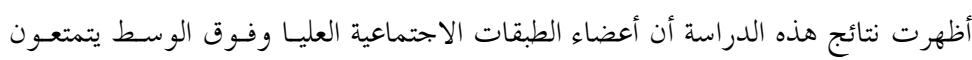

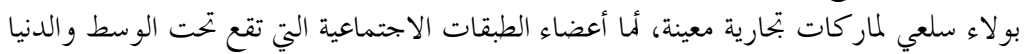

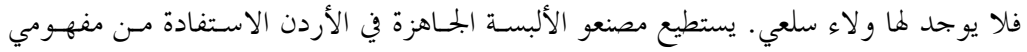

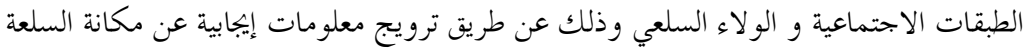

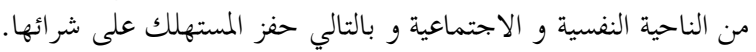

